\title{
Late Glacial-Holocene climatic transition record at the Argentinian Andean piedmont between 33 and $34^{\circ} \mathrm{S}$
}

\author{
A. E. Mehl and M. A. Zárate \\ Instituto de Ciencias de la Tierra y Ambientales de La Pampa (INCITAP, CONICET - Universidad Nacional de La Pampa), \\ Uruguay 151, Santa Rosa, La Pampa, Argentina
}

Correspondence to: A. E. Mehl (adrianamehl@gmail.com)

Received: 31 July 2013 - Published in Clim. Past Discuss.: 31 October 2013

Revised: 12 February 2014 - Accepted: 12 March 2014 - Published: 30 April 2014

\begin{abstract}
The Arroyo La Estacada ( 33 $\left.28^{\prime} \mathrm{S}, 69^{\circ} 02^{\prime} \mathrm{W}\right)$, eastern Andean piedmont of Argentina, cuts through an extensive piedmont aggradational unit composed of a dominant Late Pleistocene-early Holocene (LP-EH) alluvial sequence that includes several paleosols.

One of these paleosols developed affecting the topmost part of likely Late Glacial aeolian deposits aggraded into a floodplain environment by the end of the Late Pleistocene. The paleosol shows variable grade of development along the arroyo outcrops. Organic matter humification, carbonate accumulation and redox processes were the dominant processes associated with paleosol formation. By the early Holocene, when the formation of the paleosol ended, renewed alluvial aggradation and high magnitude flooding events affected the arroyo's floodplain environment. Accordignly, a period of relative landscape stability in the Arroyo La Estacada basin is inferred from the paleosol developed by the LP-EH transition in response to the climatic conditions in the Andes cordillera piedmont after the Late Glacial arid conditions. The analyzed Late Glacial-Holocene alluvial record of the Andean piedmont constitutes a suitable record of the LP-EH climatic transition in the extra-Andean region of Argentina. It is in agreement with regional paleoclimatic evidence along the southern tip of the South American continent, where other pedosedimentary sequences record similar late Quaternary paleoenvironmental changes over both fluvial and interfluvial areas.
\end{abstract}

\section{Introduction}

The understanding of earth's past climatic evolution is considered the key to get a better understanding of the presentday climatic system and the development of long-term climatic change forecasts (Saltzman, 2002). In particular, since the Last Glacial Maximum (LGM), ice sheet retreat and the amelioration of climate leading to our present climate conditions have not been uniform processes (Saltzman, 2002; p. 39). Specifically, at the southern tip of South America, the late Quaternary paleoclimatic conditions have been mainly revealed by the glacial fluctuations in the Andes cordillera (Clapperton, 1993; Espizua, 1993, 1998, 1999; Coronato and Rabassa, 2007; Rabassa, 2008). More recently, during the last decade there has been increasing interest in late Quaternary paleoenvironmental and paleoclimatic conditions of the extra-Andean region of central Argentina. As a result, studies have been focused on the analysis of different proxies (Villalba, 1990; Prieto, 1996; Piovano et al., 2002; Zárate and Paéz, 2002; Prieto et al., 2003; Kemp et al., 2006; Boninsegna et al., 2009; Rojo et al., 2012a; Navarro, 2012). In particular, the study of buried paleosols has been concentrated in the loess sequences that dominate the Pampean region, where the largest loess plain of South America has developed with a nearly $50 \mathrm{~m}$ thick loess record (Fig. 1a). In fact, the eastern region of the Pampean plain has been a classic area to analyze Quaternary Argentinean paleosols (Teruggi and Imbellone, 1987; Imbellone and Teruggi, 1993; Blasi et al., 2001; Zárate et al., 2002; Kemp et al., 2004b; Imbellone and Cumba, 2003, among others). Also, some studies were conducted in the loess-paleosol sequence of northwestern Argentina with the aim of inferring 


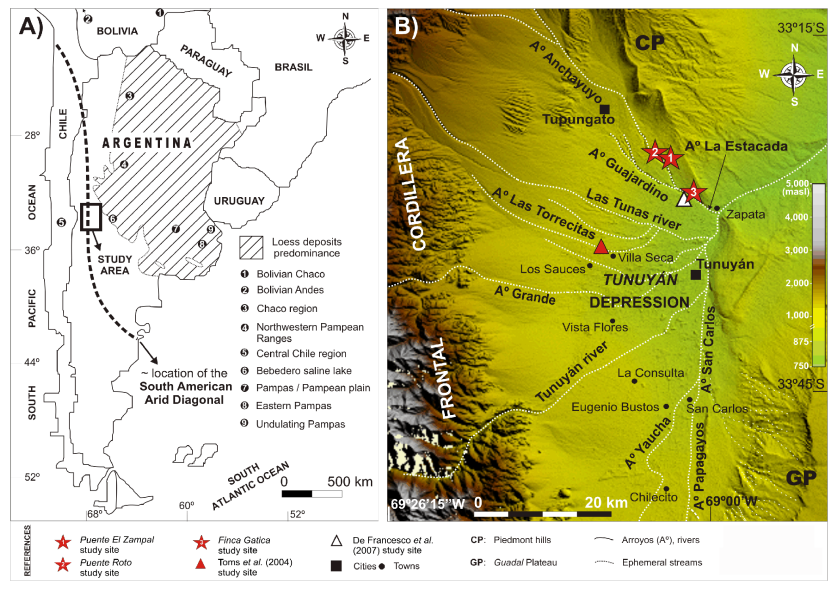

Fig. 1. (A) Location map. Approximate distribution of loess deposits in Argentina (Zinck and Sayago, 1999) and extension of the South American Arid Diagonal. (B) Digital elevation model and fluvial drainage at the eastern Andean piedmont between 33 and $34^{\circ} \mathrm{S}$, Mendoza province, Argentina.

paleoenvironmental conditions during the Late Pleistocene and early Holocene (Kemp et al., 2003, 2004a) (Fig. 1a). In spite of this, loess deposits of Argentina commonly lack the stratigraphical resolution to analyze the approximately last 14 kyr paleoclimatic-paleoenvironmental conditions (Zárate et al., 2000). As a consequence, and taking into account the large potential of South American fluvial systems for paleoclimatic research (Baker, 2000; Zárate et al., 2000; Latrubesse, 2003), many studies have been concentrated on the analysis of alluvial sequences of the Pampean plain (Fidalgo et al., 1973; Zárate et al., 2000; Prieto et al., 2004; Quattrocchio et al., 2008; Zech et al., 2009). Some of them combine information from fluvial sedimentology, pedology and biological proxies and provide altogether a more comprehensive framework for the understanding of Late Glacial and Holocene paleoenvironmental-paleoclimatic conditions in Argentina.

Particularly, in the piedmont of the Andes frontal cordillera in Mendoza province, central-western Argentina, the Late Glacial and Holocene climatic changes are recorded in the alluvial sequences exposed the alluvial sequences exposed in the riverbanks of the fluvial systems draining the piedmont (Fig. 1b). In the Arroyo La Estacada fluvial basin (eastern Andean piedmont, $\sim 33^{\circ} 28^{\prime} \mathrm{S}$ and $69^{\circ} 02^{\prime} \mathrm{W}$ ), there is a well-constrained and laterally traceable paleosol with a formation interval that began ca. $12 \mathrm{cal} \mathrm{kyr} \mathrm{BP}$ and lasted until ca. 10.6 cal kyr BP (Zárate and Páez, 2002; Mehl and Zárate, 2012). The paleosol was developed over likely Late Glacial aeolian silty sands aggraded in a paleo-floodplain surface located in a distal alluvial fan position (Mehl and Zárate, 2012) featured by fluvial processes related to overbank sheet fluid overflows and probably temporary inactive channels of sandy braided streams (Mehl and Zárate,
2012). Paleosol formation was outpaced by a renewal of fluvial aggradation with a likely higher magnitude of flooding events (Zárate and Mehl, 2008; Mehl and Zárate, 2012).

Here we present results from field and micromorphological analyses of LP-EH transition in the alluvial sequences exposed at the banks of Arroyo La Estacada. Our identification and description of sedimentological and local-scale pedogenic processes in central-western Argentina during the LP-EH transition contributes a new paleoclimatic context in this region. A regional correlation with other synchronous records of the extra-Andean region of southern South America is also made to contribute, at a continental scale, to the knowledge of the late Quaternary climatic system and its variability.

\section{Regional setting and geological background}

The study area comprises the fluvial basin of Arroyo La Estacada, $\sim 33^{\circ} 28^{\prime} \mathrm{S}$ and $69^{\circ} 02^{\prime} \mathrm{W}$, in Mendoza province, Argentina. The region presents an arid-semiarid climate (Burgos and Vidal, 1951; Prohaska, 1961). The mean annual temperature is $12.8^{\circ} \mathrm{C}$, and the ca. $200 \mathrm{~mm}$ average annual rainfall is mostly related to short but relatively heavy rains during the austral spring and summer seasons (Barros and Silvestri, 2002). Vegetation corresponds to the "Monte" province according to Cabrera's phytogeographical classification (1976) and is dominated by xerophytic shrublands (Roig and Martínez Carretero, 1998). Nonetheless, hydrophytic communities grow where water is locally available (Rojo et al., 2012a). The region is included in the South American Arid Diagonal (SAAD) (Fig. 1a), an ecotone fringe characterized by particularly high sensitivity for past and present atmospheric circulation changes along its margins (Abraham de Vázquez et al., 2000; Piovano et al., 2009). The SAAD comprises a narrow belt of land that records a moisture source of Atlantic influence towards the north and east (subtropical summer rain regime), and a Pacific influence to the western and south-western areas (mainly dominated by winter precipitations) (Bruniard, 1982; Piovano et al., 2009).

The Arroyo La Estacada drains to the Tunuyán River basin (Fig. 1b), the main river of this piedmont area, also receiving inputs from other minor rivers and arroyo systems. The arroyo, of meandering pattern and perennial discharge, is fed by springs located along a fault line and also by Arroyo Anchayuyo, a stream collecting water in a catchment area dominated by Paleogene deposits (Fig. 1b).

The geological setting of the study area corresponds to the piedmont of the frontal cordillera, the eastern morphostructural unit composing the Andes cordillera at this latitude (Fig. 1a and b). The frontal cordillera is formed by a Proterozoic metamorphic complex, Carboniferous-Permian sedimentary rocks, a wide eruptive intrusive igneous record of Permian-Triassic age, and Quaternary volcanic rocks 

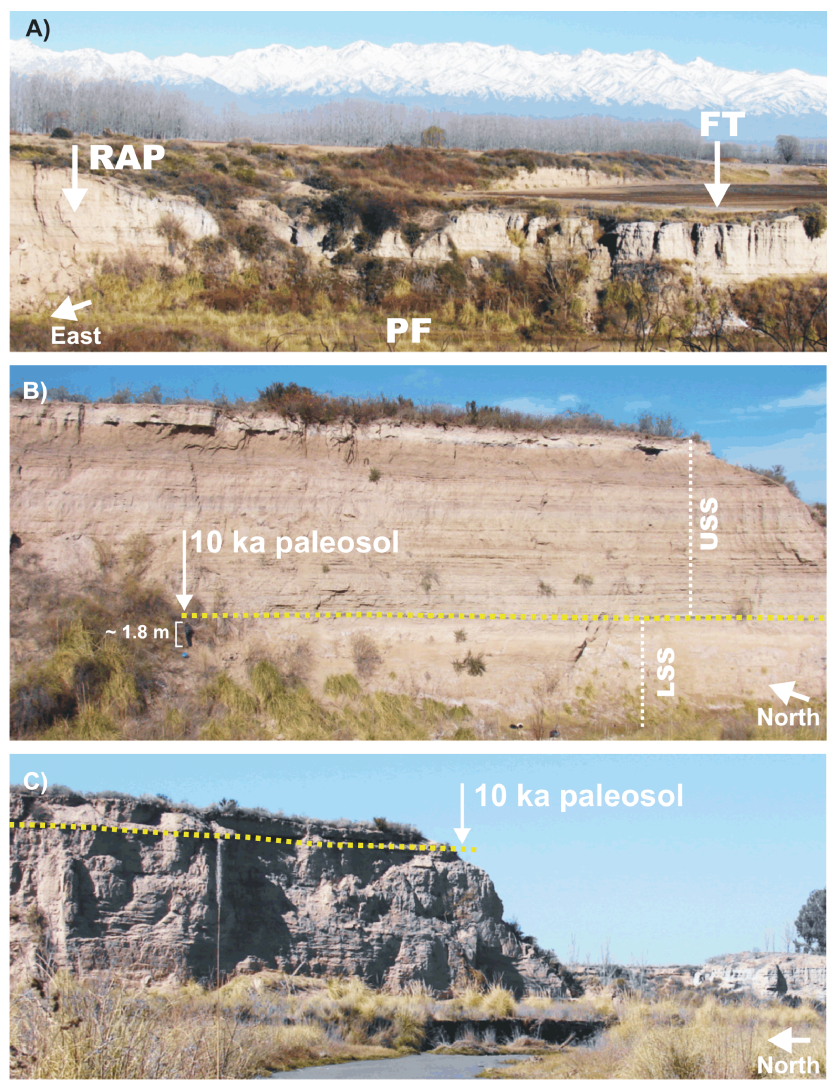

Fig. 2. Late Pleistocene-Holocene alluvial sequence at Arroyo La Estacada. (A) View of the three geomorphological units differentiated at the arroyo valley: regional aggradational plain (RAP), fill terrace (FT) and present floodplain (PF) (Zárate, 2002; Zárate and Mehl, 2008). (B) Puente El Zampal study site: RAP unit at the cut bank of Arroyo Anchayuyo; lower and upper stratigraphic sections (LSS, USS) are shown. (C) RAP at Finca Gatica study site, Arroyo La Estacada.

(Caminos, 1993; Azcuy, 1993; Llambías et al., 1993; Sruoga et al., 2005, among others). Arroyo La Estacada is located in the northern tip of the Tunuyán Depression, a Quaternary tectonic basin developed in the piedmont area and filled with middle to late Quaternary sediments (Polanski, 1963). The arroyo stream cuts the Tunuyán Depression through an extensive aggradational geomorphological unit called a regional aggradational plain (RAP) sensu Zárate and Mehl (2008) (Figs. $1 \mathrm{~b}$ and 2a). The RAP is characterized by a flat and gently steepening topography dropping from near $1300 \mathrm{~m}$ a.s.l. at the footslope of the frontal cordillera mountain front to around $700 \mathrm{~m}$ a.s.l. to the east where folded and thrusted Miocene deposits bound the tectonic depression (Guadal Plateau and Piedmont Hills - Cerrilladas Pedemontanas; Yrigoyen, 1993; Fig. 1b). The RAP sedimentary sequence is included in the El Zampal Formation (Zárate and Mehl, 2008), previously La Estacada and El Zampal Formations according to Polanski (1963), that would likely record at least the last $120 \mathrm{ka}$, with the oldest exposures of ca. $50 \mathrm{ka}$ located along the riverbanks of the arroyos crossing the area (Toms et al., 2004; Zárate and Mehl, 2008). The Arroyo La Estacada excavated a nearly $20 \mathrm{~m}$ deep valley in the RAP deposits followed by the aggradation of a middle-late Holocene fluvial sequence presently arranged in a fill terrace geomorphological unit (Fig. 2a).

The RAP sedimentary deposits, comprising the LP-EH transition interval, are divided into a lower and an upper stratigraphic section, LSS and USS respectively (Zárate and Mehl, 2008) (Fig. 2b). The LSS is dominantly composed of homogeneous massive sand beds laterally continuous with variable thickness resulting from overbank flows blanketing inactive areas of sandy braided channels. Also, some hyperconcentrated flow deposits, channel lag and/or longitudinal bar deposits were inferred from the presence of lenses made up of well-rounded fine to coarse rock clasts (Mehl and Zárate, 2012). The uppermost $2 \mathrm{~m}$ of the LSS record a homogeneous and massive fine sand to silty sand deposit of likely aeolian origin with pedological features on top giving way to a buried soil laterally traceable for nearly $12 \mathrm{~km}$ along the Anchayuyo and La Estacada arroyos riverbanks (Zárate and Mehl, 2008; Mehl and Zárate, 2012). The minimum interval of paleosol formation was dated from ca. 11709$12075 \mathrm{cal}$ yr BP to ca. $10685-11144$ cal yr BP (minimum numerical ages reported by Mehl and Zárate, 2012).

The USS is developed on top of the paleosol (Fig. 2b). Its base is dominated by beds of horizontally laminated and massive sandy silts and clayey silts of variable thickness. They are interbedded with thin massive either horizontally laminated or ripple cross-laminated fine sand to silty sand layers. Limnic levels are very common throughout these deposits, with the lowermost yielding a date of 1039110753 cal yr BP (Mehl and Zárate, 2012). These sediments were interpreted as deposited from suspension, likely blanketing inactive areas of sandy braided channels, with occurrence of weak traction currents generating lower-flow-regime bed forms (Mehl and Zárate, 2012). The USS middle and upper parts show interbedded massive silty sand and sandy silt layers. Two abutting paleosols develop near $6 \mathrm{~m}$ depth, the upper one dated at 8454-8968 cal yr BP (Mehl and Zárate, 2012). Also, $1.5 \mathrm{~m}$ below the surface a paleosol was dated at 2967-3211 cal yr BP (Zárate and Mehl, 2008). In some positions of the fluvial basin it is overlaid by a moderately to highly gypsum and silica cemented hardpan. A superficial massive and loose fine aeolian sand blankets the uppermost part of the RAP (Mehl and Zárate, 2012).

\section{Methodology}

Three locations were chosen to illustrate the different degree of pedological development of the ca. $10 \mathrm{ka}$ paleosol along the Arroyo La Estacada basin. Fieldwork was carried out at Puente El Zampal (PEZ; $33^{\circ} 26^{\prime} 52^{\prime \prime} \mathrm{S}-69^{\circ} 03^{\prime} 09^{\prime \prime} \mathrm{W}$ ) and Puente Roto study sites (PR; $33^{\circ} 26^{\prime} 25^{\prime \prime} \mathrm{S}-69^{\circ} 03^{\prime} 32^{\prime \prime} \mathrm{W}$ ), 


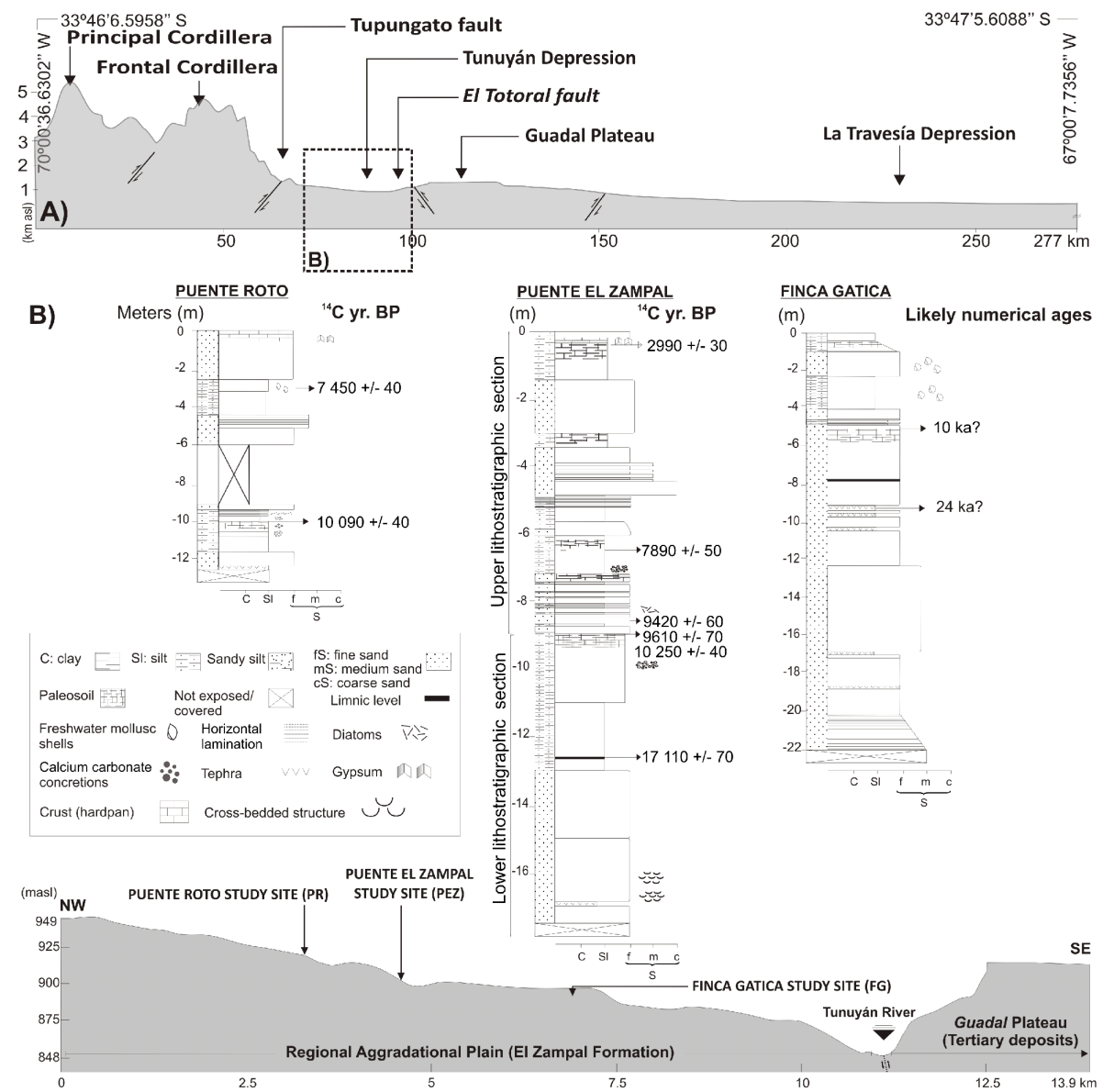

Fig. 3. (A) Sketch showing the main morphostructural units at the study area (vertical scale is exaggerated). Tunuyán Depression study area is boxed. (B) Schematic topographic profile (adapted from Google Earth software) along the regional aggradational plain in the vicinities of the arroyos Anchayuyo and La Estacada riverbanks. Lithostratigraphic field logs at each study site are shown.

both located at the riverbanks of the lower reach of Arroyo Anchayuyo (Fig. 3), which contributes its waters, together with Arroyo Guajardino, to Arroyo La Estacada. The third study site selected was Finca Gatica $\left(33^{\circ} 28^{\prime} 12^{\prime \prime} \mathrm{S}-\right.$ $69^{\circ} 02^{\prime} 19^{\prime \prime} \mathrm{W}$ ), located at Arroyo La Estacada (Fig. 3). A distance of $1 \mathrm{~km}$ exists between PR and PEZ study sites; in turn FG is 4 and $3 \mathrm{~km}$ far away from both study sites respectively (Figs. $1 \mathrm{~b}$ and 3 ).

The results obtained from the pedosedimentary analysis of the LP-EH transition paleosol are interpreted and discussed on the basis of sedimentological, lithofacial, stratigraphical and geochronological data already reported by Zárate and Mehl (2008) and Mehl and Zárate (2012) (Fig. 3; Table 1). Field identifications and descriptions were conducted following the main criteria pointed out by Tucker (2003), Catt (1990) and the Soil Survey Staff (1999, 2003). Drysediment colors are reported according to Munsell Soil Color Chart (2000) (Table 1). Wet oxidation followed by titration with ferrous ammonium sulfate was used to determine the organic matter content (Walkley \& Black's method) in pa- leosol sediments (Table 1), using the Van Bemmelen factor (1.72), which assumes $58 \%$ of total organic carbon in soil organic matter. Calcium carbonate content was determined by using a pressure digital calcimeter apparatus and $18 \mathrm{~mL}$ of $15 \% \mathrm{HCl}$ for each sample measured (Table 1).

A micromorphological analysis was conducted to help with the detection of post-depositional pedological features. The PEZ study site was selected as a key section to conduct the micromorphological analysis as it shows the best development of the ca. $10 \mathrm{ka}$ paleosol in the field. The analysis was focused on the depth interval between 7.35 and $10 \mathrm{~m}$ of the alluvial sequence profile (topmost paleosol part is placed approximately at a $9 \mathrm{~m}$ depth, Fig. 4). On the contrary, the FG study site was chosen to analyze the paleosol in a position showing a low degree of pedological development. Due to access difficulties, micromorphological analysis at the FG profile was restricted to the paleosol section of approximately $0.3 \mathrm{~m}$ thick, and placed at a depth of near 4.5 in the alluvial sequence profile (Fig. 6). 
Table 1. Late Pleistocene-Holocene transition paleosol: horizonation, structure, air-dried color sample (Munsell Soil Color Chart, 2000), limits, organic matter $(\mathrm{OM})$-calcium carbonate $\left(\mathrm{CaCO}_{3}\right)$ contents, and radiocarbon ages at the three involved study sites. Calibrated radiocarbon ages: Calib 6.1.0 Program (Stuiver, Reimer \& Reimer Copyright 1986-2011, http://calib.qub.ac.uk/calib/) and McCormac et al. (2004) calibration data sets were used.

\begin{tabular}{|c|c|c|c|c|c|c|c|c|c|c|c|c|c|}
\hline \multirow{2}{*}{ 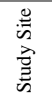 } & \multirow{2}{*}{ 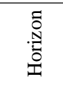 } & \multirow{2}{*}{ 莺 } & \multirow{2}{*}{ 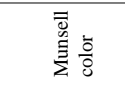 } & \multicolumn{2}{|c|}{ Limit } & \multirow{2}{*}{$\sum_{0}^{\circ}$} & \multirow{2}{*}{$\delta_{j}^{\infty}$} & \multicolumn{6}{|c|}{ Radiocarbon ages } \\
\hline & & & & 岕 & 产 & & & Lab no. & Material & ${ }^{14} \mathrm{C}$ Age (BP) & $\delta^{13} \mathrm{C}$ & Calibrated age $(2 \sigma)$ & Author \\
\hline \multirow{6}{*}{ 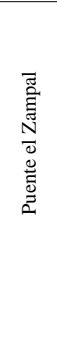 } & & \multirow{6}{*}{ 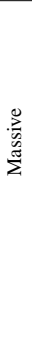 } & \multirow[b]{2}{*}{$\begin{array}{l}10 \text { YR } 6 / 1- \\
10 \text { YR } 6 / 2\end{array}$} & \multirow{6}{*}{ 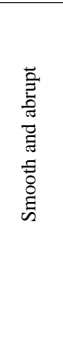 } & \multirow{6}{*}{ 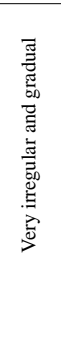 } & \multirow[b]{2}{*}{1.33} & \multirow[b]{2}{*}{0.2} & NSRL-12 644 & OM & $2990 \pm 30$ & -15.0 & $2967-3211(p: 1)$ & Zárate and Mehl (2008) \\
\hline & & & & & & & & Beta-135581 & $\mathrm{OM}$ & $7890 \pm 50$ & -25.0 & $\begin{array}{c}8454-8968(p: 0.96) \\
8832-8862(p: 0.022) \\
8890-8890(p: 0.0004) \\
8919-8952(p: 0.019) \\
8964-8968(p: 0.002)\end{array}$ & Zárate and Mehl (2008) \\
\hline & \multirow{4}{*}{$\mathrm{C}$} & & \multirow{4}{*}{$10 \mathrm{YR} 7 / 2$} & & & \multirow{4}{*}{0.40} & \multirow{4}{*}{1.20} & Beta- 135580 & OM & $9420 \pm 60$ & -25.0 & $\begin{array}{l}10303-10314(p: 0.005) \\
10391-10753(p: 0.995)\end{array}$ & Zárate and Mehl (2002) \\
\hline & & & & & & & & Beta-135579 & OM & $9610 \pm 60$ & -25.0 & $10685-11144(p: 1)$ & Zárate and Mehl (2002) \\
\hline & & & & & & & & NSRL-12643 & OM & $10250 \pm 40$ & -15.8 & $11709-12075(p: 1)$ & Mehl and Zárate (2012) \\
\hline & & & & & & & & Beta-154137 & OM & $17110 \pm 70$ & -21.0 & Calibration curve is not valid* & Zárate and Páez (2002) \\
\hline \multirow{2}{*}{ 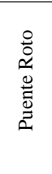 } & A & \multirow[t]{2}{*}{ 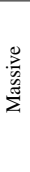 } & $10 \mathrm{YR} 6 / 2$ & \multirow{2}{*}{ 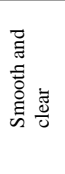 } & \multirow{2}{*}{ 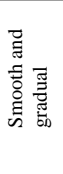 } & $\begin{array}{c}1.95- \\
1.34\end{array}$ & $\begin{array}{c}1.30- \\
1.80\end{array}$ & NSRL-12645 & $\begin{array}{c}\text { Mollusk } \\
\text { shell }\end{array}$ & $7450 \pm 40$ & -6.4 & $\begin{array}{c}8050-8093(p: 0.058) \\
8106-8119(p: 0.012) \\
8133-8139(p: 0.005) \\
8155-8345(p: 0.92)\end{array}$ & This paper \\
\hline & $\begin{array}{c}\text { Ck or } \\
\mathrm{Bk} ?\end{array}$ & & $10 \mathrm{YR} 8 / 3$ & & & 0.35 & 15.60 & Beta-154136 & $\mathrm{OM}$ & $10090 \pm 50$ & -18.3 & $\begin{array}{c}11275-11770(p: 0.99) \\
11790-11805(p: 0.007)\end{array}$ & This paper \\
\hline \multirow{2}{*}{ 总 } & A & \multirow{2}{*}{ 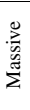 } & $10 \mathrm{YR} 6 / 2$ & \multirow{2}{*}{ 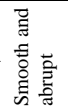 } & \multirow{2}{*}{ 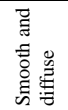 } & 0.13 & 2.5 & & & & \multirow{2}{*}{-} & & \\
\hline & $\mathrm{C}$ & & $10 \mathrm{YR} 6 / 2$ & & & 0.27 & 3.1 & & & & & & \\
\hline
\end{tabular}

* Southern Hemisphere calibration curve is not valid to calibrate this age. $2 \sigma: 2$ sigma standard deviation. $p$ : probablity.

Micromorphological analysis was carried out on thin sections made from undisturbed blocks collected at convenient intervals in Kubiena tins $(7 \mathrm{~cm} \times 5 \mathrm{~cm} \times 4 \mathrm{~cm})$, then air dried and impregnated with epoxy resin according to standard procedures (Lee and Kemp, 1992). Thin sections were described under a Nikon Eclipse E400 Pol petrological microscope with $10-400 \times$ magnification following the terminology and criteria proposed by Bullock et al. (1985) and Catt (1990). Observed key micromorphological features (fabric, structure-microstructure, coarse/fine materials, basic components, groundmass and pedofeatures) are quantified and summarized into tables attached to Figs. 4 and 6.

\section{Results}

\subsection{Macroscopic features of the Late Pleistocene-Holocene transition paleosol}

\subsubsection{Puente El Zampal study site}

At PEZ study site the ca. $10 \mathrm{ka}$ paleosol is $9 \mathrm{~m}$ below the RAP surface and $7 \mathrm{~m}$ above the Arroyo Anchayuyo water level (Figs. 2b and 3). It exhibits an A/C profile with a thickness of nearly $0.4 \mathrm{~m}$, and it is characterized by a massive appearance and high firmness. When broken in the hand, it has blocky structure. Color varies downward from gray (10YR $5 / 1,6 / 1)$-light brownish gray (10YR 6/2) to light gray (10YR $7 / 1,7 / 2$ ) (Table 1). Organic matter decreases in the same way from 1.33 to $0.40 \%$ while calcium carbonate content passes downward from non-calcareous to very slightly calcareous (Table 1). Approximately $0.65 \mathrm{~m}$ below the paleosol, there are calcitic nodules grading into calcitic mottles towards the lower levels. Numerical ages reported for this paleosol were obtained from the topmost and lowermost part of the A horizon: 10685-11 144 cal yr BP and 11709-12075 cal yr BP respectively (Table 1 ).

\subsubsection{Puente Roto study site}

At this study site the paleosol is $10 \mathrm{~m}$ below the RAP surface and near $10 \mathrm{~m}$ above the Arroyo Anchayuyo water level (Fig. 3). It exhibits an upper A horizon and a preliminary described $\mathrm{Ck}$ or Bk horizon. Faint color changes downward in a gradual way from light brownish gray (10YR 6/2) to very pale brown (10YR 7/3, 8/4) (Table 1). Organic matter content reaches up to $2 \%$ but decreases markedly toward the paleosol base (Table 1). Calcium carbonate content changes from slightly calcareous in the paleosol upper part to very calcareous in the base exhibiting calcitic nodules. Also, there are calcitic concretions at a depth of approximately $0.6 \mathrm{~m}$ below the paleosol (Table 1). A calibrated radiocarbon age of 11275-11805 yr BP was reported from the organic matter content of the paleosol topmost part (Table 1). 


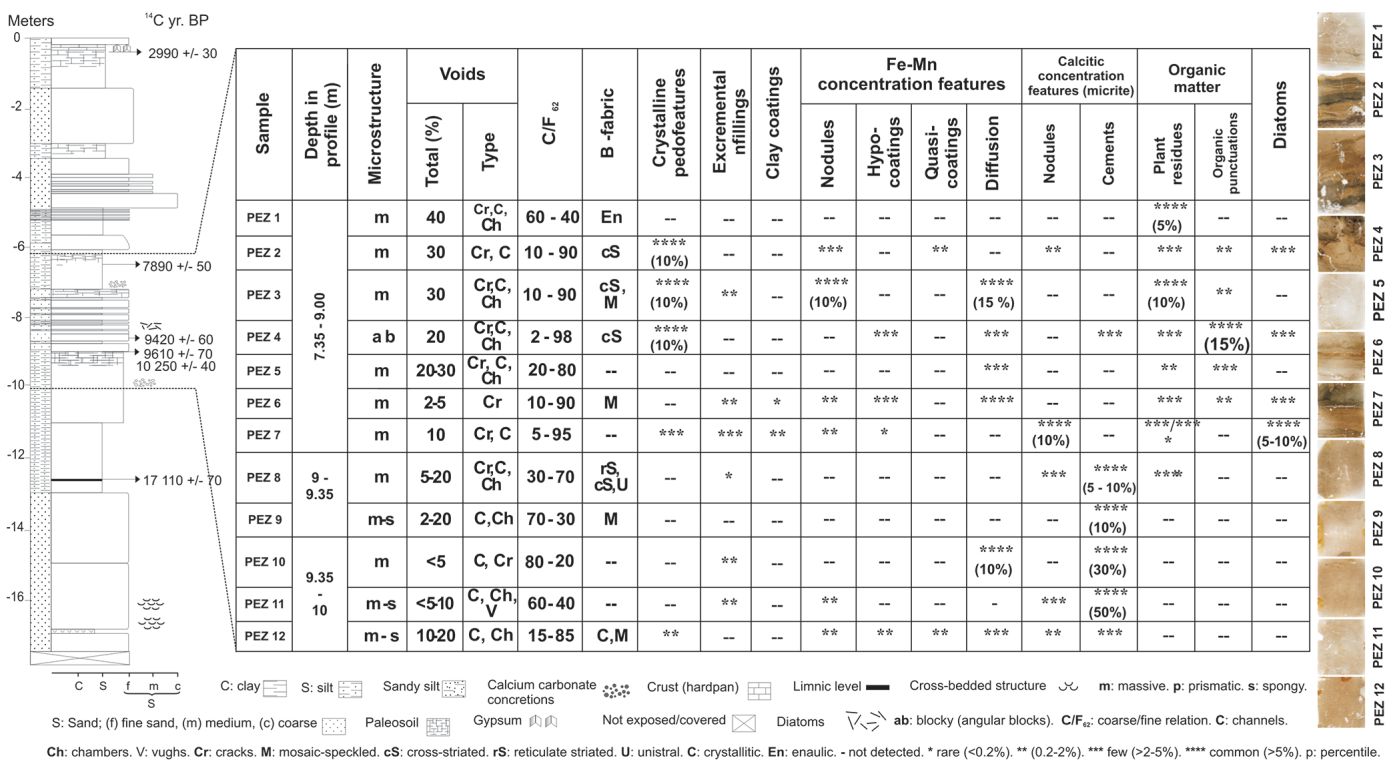

Fig. 4. Alluvial sequence field log at Puente El Zampal study site (Arroyo Anchayuyo) and micromorphology of the ca. $10 \mathrm{ka}$ paleosol.

\subsubsection{Finca Gatica study site}

At FG study site, the LP-EH paleosol is placed at a depth of $4.5 \mathrm{~m}$ from the RAP surface and near $15 \mathrm{~m}$ above the Arroyo La Estacada water level. In this location, the paleosol exhibits a relatively higher paleotopographic position and a poorer degree of pedological development when compared with PEZ and PR exposures (Fig. 3). It shows a thickness of $0.3 \mathrm{~m}$, an $\mathrm{A}-\mathrm{C}$ horizonation and a massive structure. Color changes from light brownish gray (10YR 6/2) in the paleosol upper part to very pale brown (e.g., 10YR7/3, 8/4) at the base (Table 1). Paleosol organic matter content is low, showing a very minor increase downward (Table 1). The same happens with calcium carbonate content resulting in a slightly calcareous paleosol base (Table 1), where some isolated powdery concentrations of calcium carbonate can be observed. The paleosol has not been dated at this site. Nonetheless its Late Glacial to early Holocene age was inferred from its position $10 \mathrm{~m}$ above a tephra level correlated with the 24 to $30 \mathrm{ka} \mathrm{BP}$ tephra layers dated by Toms et al. (2004) at Brazo Abandonado $\left(33^{\circ} 28^{\prime} 13^{\prime \prime} \mathrm{S}\right.$ and $\left.69^{\circ} 02^{\prime} 39^{\prime \prime} \mathrm{W}\right)$ study site, $1.5 \mathrm{~km}$ downstream from FG study site.

\subsection{Micromorphological aspects}

\subsubsection{Puente El Zampal micromorphology}

The deposits immediately underlying the ca. $10 \mathrm{ka}$ paleosol (samples: PEZ 10, 11 and 12; Fig. 4) exhibit homogeneous coarse silt and sandy silt to clay sediments $(\sim \mathrm{C} / \mathrm{F} 62$ : 80-20, 60-40 and 15-85) without an appreciable organic matter content and a relative dearth of bioturbation features. The matrix is characterized by a massive microstruc- ture and a crystallitic B-fabric. Typic calcitic nodules and zones with diffuse impregnation of calcium carbonate are a common feature of these samples, occasionally associated with a spongy microstructure (Fig. 5a). There are few calcitic hypocoatings around voids. Rare clay hypocoatings and excrements infilling voids are observed along the sections (Fig. 5b). In addition, concentrations of isotropic materials (e.g., organic matter, tephra, diatoms or phytoliths) could also be seen. Very few to few ferruginous features (nodules, hypo-quasicoatings and diffusion features) (Fig. 5c) are also observed.

The LP-EH transition paleosol (samples: PEZ 8 and 9; Fig. 4) shows a sedimentary matrix dominated by sandy silt to silty sand textures ( C/F62: 30-70 and 70-30; Fig. 4). The upper soil horizon, attributable to an A horizon (sample: PEZ 5 8; Fig. 4), presents a weak grade of pedality and a B-fabric varying across the thin section among crossstriated, reticulate striated and unistral. Although the soil mass exhibits a general homogeneous appearance related to a massive microstructure, some thin section areas exhibit spongy microstructure linked to bioturbation features (channels and 10 chambers, some of them showing mamillate surface walls). There are spheroid aggregates smaller than $74 \mu \mathrm{m}$ associated with voids, and excremental features are rare. This soil horizon has common partially degraded plant residues (Fig. 5d) with a dominantly random distribution. Nevertheless, several root fragments are preserved inside vertical to subvertical channels. Few calcitic nodules and common cemented zones are observed along with concentrations of isotropic materials assigned to glass shards.

Although the lower $\mathrm{C}$ horizon (sample: PEZ 9; Fig. 4) shows a predominance of massive microstructure, scarce zones develop weak spongy microstructure (Fig. 5e). The 

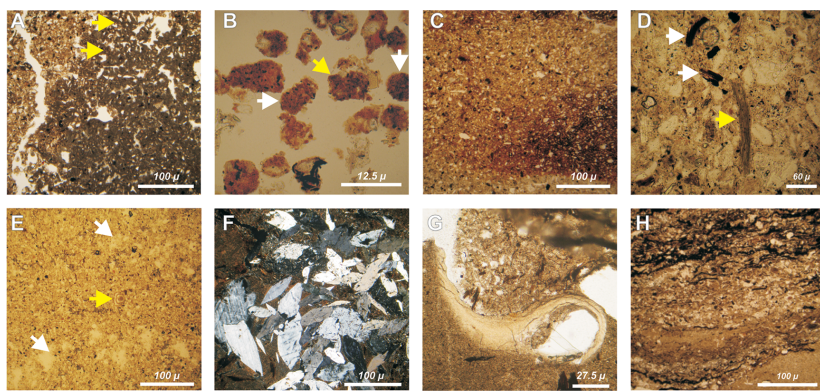

Fig. 5. Puente El Zampal (PEZ) locality: photomicrographs of micromorphological features (PPL: plane polarized light. XPL: crossed polarized light). (A) Calcitic concentration feature and spongy microstructure (arrows) (sample: PEZ 12, PPL). (B) Spherical, bacillo-cylinder (white arrows) and irregular (yellow arrow) excrement pedofeatures infilling a void (sample: PEZ 11, PPL). (C) Ferruginous impregnation in the soil mass (sample: PEZ 10, PPL). (D) Unidentified particles of organic matter (white arrows) and a tissue residue (yellow arrow) (sample: PEZ 8, PPL). (E) Concentric clay coating in a void (yellow arrow) and spongy microstructure in the bottom/right upper areas of the thin section (white arrows) (sample: PEZ 9, PPL). (F) Gypsum crystals aggregate (sample: PEZ 4, XPL). (G) Chamber clay infill (sample: PEZ 11, PPL). (H) Plant residues included into different grain size sedimentary layers (sample: PEZ 2, PPL).

sedimentary matrix is formed mainly by very fine sand to coarse silt grains $(\sim \mathrm{C} / \mathrm{F} 62: 70-30)$. Nonetheless a mosaicspeckled B-fabric can be observed due to the presence of clays in the soil mass. Organic matter concentration is not appreciable in this soil horizon; there are common weak calcitic impregnations $(>10 \%)$ that turn stronger in the upper and lower zone of the thin section. Also some rare calcitic hypocoatings develop around voids, and some scarce ferruginous concentrations are observed.

The $1.5 \mathrm{~m}$ thick sedimentary deposit resting on the LPEH transition paleosol (samples: from PEZ 1 to 7; Fig. 4) exhibits laminated horizontal layers with variable grain sizes (including fine sand, silt and clayey silt) and common horizontally aligned platy mica grains. Cross-striated and mosaic-specked B-fabrics dominate the sedimentary matrix, but enaulic B-fabric is also observed. Along this sedimentary sequence interval, ferruginous-manganiferous nodules and diffusion features are common to few while gypsum crystal aggregates are common in some samples (samples: PEZ 2, 3 and 4; Fig. 5f). In general, calcitic concentrations are scarce. Although voids reach up to $40 \%$ of the thin section surface, there are areas with a porosity of only $2 \%$. Most of the voids correspond to channels and chambers. Excrements, when present, are linked to voids. Rare clay coatings are observed inside some chambers (Fig. 5g). Plant residues exhibiting a horizontal alignment, including root fragments among them, are common in some levels (Fig. 5h). Besides organic matter, punctuation is common in the lower levels of this interval where common to few diatoms are also observed.

\subsubsection{Finca Gatica micromorphology}

At FG study site, the ca. $10 \mathrm{ka}$ paleosol profile is dominated by silt to clay sediments ( $\sim$ C/F62: 30-70; Fig. 6). Porosity varies across the paleosol reaching up to $10-15 \%$ in the upper horizon where voids are related to vughs and channels, the latter mostly likely linked to roots. Some chambers with mamillate surface roughness are observed (Fig. 7a and b). Porosity increases to $20-25 \%$ in the middle paleosol zone corresponding mainly to vughs and cracks (Fig. 7c), with the first probably relating to soil microfauna activity. At the paleosol base, some channels and chambers can be recognized, but porosity is in general lower than $5 \%$.

Calcitic concentration features are seen throughout the profile. Micrite is most abundant in the middle paleosol section and is possibly linked to water movement through the soil mass (Fig. 7c and d). In turn, at the top and base of the paleosol most of the micritic concentrations are restricted to voids (Fig. 7e), likely in relation to water passing through them or to plant root respiration. However some rare diffusion features can be observed at this section (Fig. 7f). Typic micrite nodules appear in a small proportion $(0.2-2 \%)$ at the basal horizon. Ferruginous and manganiferous concentration features are also present in the soil profile. The upper part has few ferruginous void hypocoatings and oxide diffusion features affecting the soil mass. They become common in the middle to lower part, where diffusion features are linked to almost $70 \%$ of the voids. Additionally, the middle and lower parts exhibit few nodules and very few quasicoatings of this composition.

\section{Discussion}

\subsection{LP-EH paleosol development}

The sedimentary sequence exposed at the Arroyo La Estacada fluvial basin records the occurrence of alternating aggradational and pedological processes. Organic matter humification along with calcium carbonate accumulation expressed in the formation of nodules, concretions and paleosol cemented zones were the dominant soil formation processes. Secondarily, oxidation and reduction of iron, manganese and likely sulfur occurred affecting not only the LP-EH transition paleosol mass but also the overlying paleosol deposits. At PEZ and PR study site, paleosol features are more conspicuous than at FG study site where there is a relative dearth of pedological features making its distinction in the sedimentary sequence difficult. This variable grade of paleosol development could be probably related to a paleo-location of PEZ study site in a floodplain environment proximal to the main stream crossing the area at that time. Conversely, the PR and FG paleosol exposures were likely related to more distal positions in the floodplain environment. 


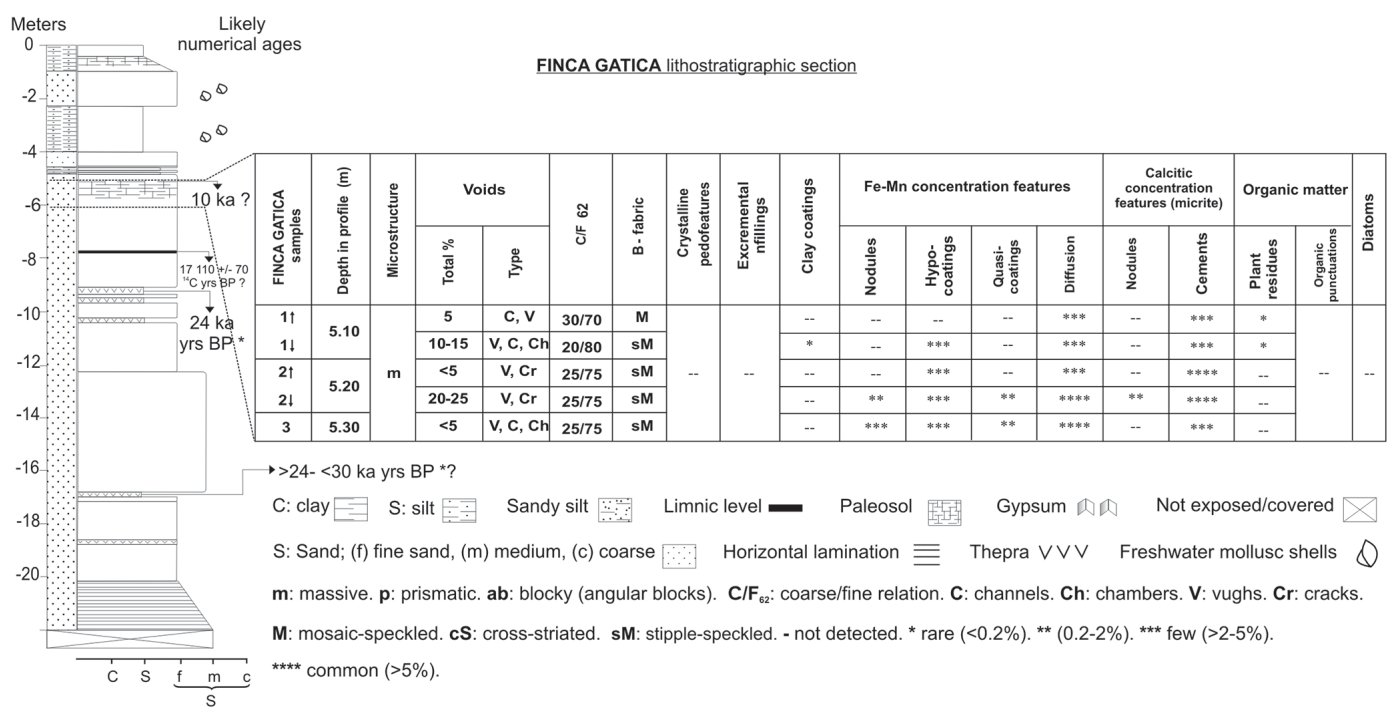

Fig. 6. Alluvial sequence field log at Finca Gatica study site (Arroyo La Estacada) and micromorphology of the ca. 10 ka paleosol. A field $\log$ in Puente Roto study site (Arroyo Anchayuyo) is also schematized.
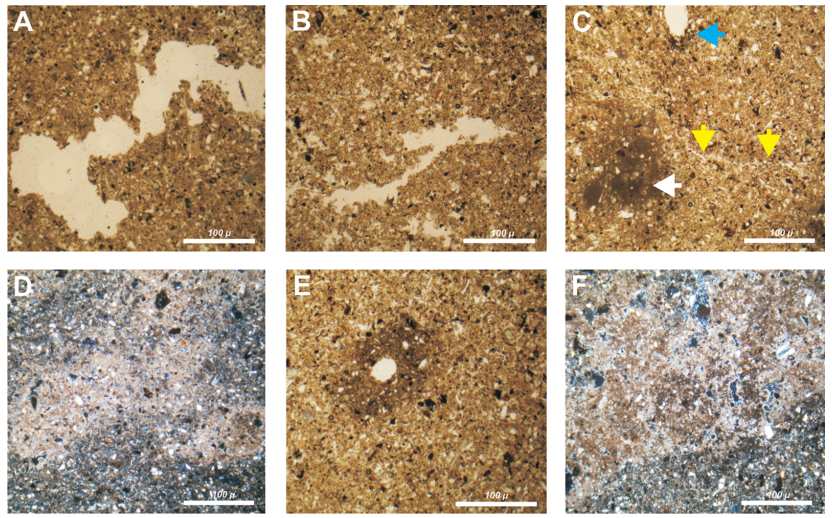

Fig. 7. Finca Gatica locality: photomicrographs of micromorphological features (PPL: plane polarized light. XPL: crossed polarized light). (A-B) Chambers with mamillate surface roughness. Microphotograph (B) also shows zones with spongy-like structure (samples: FG 1 and FG 2, PPL). (C) Calcitic impregnation (white arrow), slight hypocoating and calcitic diffusion around a void (light blue arrow) and a crack (yellow arrows) (sample: FG 2, PPL). (D) Calcitic diffusion in the soil mass (sample: FG 1, XPL). (E) Calcitic hypocoating and diffusion around a void (sample FG 1, PPL). (F) Calcitic diffusion in the soil mass (sample: FG 2, XPL).

At PEZ study site an A horizon is distinguished on the basis of a higher concentration of organic matter. Abundant plant residues are mostly in disturbed position, but others are in growth position (e.g., roots). Bioturbation features are scarce. The $\mathrm{C}$ horizon lacks abundant organic matter, and parent materials are dominant. Redox features are scarce in the paleosol. In turn they become abundant in the overlying sediments, and in minor proportion, in the underlying ones, suggesting periods of soil moisture excess and im- paired drainage. Also, neoformation gypsum crystals in the sediments overlaying the paleosol reflect transport of calcium sulfate by solution and subsequent evaporation. Horizontally arranged organic matter accumulations in the laminated sediments above the paleosol indicate the likely transport and accumulation of plant residues by fluid flows, which affected the aggradational plain once pedological processes ended ca. 10 685-11 144 cal yr BP and alluvial aggradation renewed.

At FG study site the LP-EH transition paleosol is poorly developed. An A horizon with very low organic matter concentration is distinguished based on a greater presence of bioturbation by microfauna activity than the surrounding sediments. Although calcium carbonate concentration is low in the paleosol, calcitic nodules and micritic cementations are observed at a macroscopic and microscopic level, respectively. Chemical analysis reflects a $\mathrm{C}$ horizon with slightly higher organic matter content than the A horizon, a feature that is not evident in the paleosol profile outcrop where color seems lighter toward the paleosol base. This anomalous organic matter content could be related to preferential organic matter conservation within the soil profile (with the soil's upper part being more susceptible to oxidation and organic matter losses), or to a primary higher organic matter concentration in the sediments then affected by pedogenesis.

\subsection{Late Glacial and early Holocene at the Arroyo La Estacada}

The LGM and Late Glacial in the eastern Andean piedmont between 33 and $34^{\circ} \mathrm{S}$ and the central region of $\mathrm{Ar}$ gentina were dominated by arid conditions and aeolian sedimentation (Kemp et al., 2004b, 2006; Tripaldi and Forman, 2007; Frechen et al., 2009; Tripaldi et al., 2011; Mehl and Zárate, 2012). The San Rafael plain environment ( $\left.34^{\circ} 30^{\prime} \mathrm{S}\right)$, 
in the distal Andean piedmont of Mendoza and south of the study area, has a record of a major change from dominant ephemeral fluvial deposition to aeolian aggradation after ca. $23 \mathrm{ka}$ (Tripaldi et al., 2011). The occurrence of a long dry windy interval in the region that lasted until ca. $13 \mathrm{kyr} B P$ or two dry windy intervals from ca. 23-20 and ca. 16-13 kyr BP is not yet resolve (Tripaldi et al., 2011). At the Arroyo La Estacada basin, a nearly 1-meter-thick tabular and laterally continuous aeolian deposit interbedded within the Late Pleistocene-Holocene alluvial sequence, and interpreted as an aeolian aggradation pulse in the floodplain environment of the arroyo, is thought to be a marker of arid conditions (Mehl and Zárate, 2012). Pedological processes affected the topmost part of the aeolian deposits and resulted in a paleosol that records scarce pedogenetic features. The interval of relative landscape stability across the fluvial basin dates back from 11709-12075 to ca. 10685-11 144 cal yr BP (Mehl and Zárate, 2012). Prior to ca. $10000{ }^{14} \mathrm{C}$ yr BP the pollen assemblage of the Arroyo La Estacada record is linked to regional climatic conditions of extreme aridity (Zárate and Páez, 2002). Subsequently, it suggests regional conditions of increasing temperature, which could have favored paleosol development (Zárate and Páez, 2002). Also, an increased availability of water in the basin is reported (Zárate and Páez, 2002). By the early Holocene, a renewal of fluvial aggradation is recorded by laminated epiclastic sediment layers interbedded with highly organic sediments. Sedimentological, lithofacial and geochronological analyses indicate that the early Holocene has a higher stratigraphic resolution at the PEZ and PR lithostratigraphic profile area (Fig. 3; Mehl and Zárate, 2012). There, the sedimentological record might express a closer position to the main channel by that time, not evidenced at FG lithostratigraphic profile. However, the sedimentological arrangement of the early Holocene sediments could also indicate the occurrence of flooding events of different magnitudes that affected the floodplain environment.

\subsection{Regional correlations}

\subsubsection{Pedosedimentary records}

In the Pampas of Argentina, the interfluve areas of the northern and eastern Pampas of Buenos Aires province (Fig. 1) preserve a paleosol known as Puesto Callejón Viejo sensu Fidalgo et al. (1973) and formed over Late Glacial sandy loess deposits (La Postrera Formation; Fidalgo et al., 1973) under a prevailing subhumid dry climate (Zárate et al., 2002). By the end of the Late Pleistocene and the early Holocene, loess aggradation dominated the undulating Pampa region (Pampa Ondulada, Fig. 1). Then, land surface stabilization gave way to the development of a paleosol that has remained at surface from then onwards (Kemp et al., 2006). On the other hand, the fluvial basins of the main rivers of the Pampas of Buenos Aires province record the development of a LP-EH paleosol on top of Late Pleistocene alluvial sequences (Luján Forma- tion; Fidalgo et al., 1973; Zárate et al., 2000; Prieto et al., 2004; Quatrocchio et al., 2008; Zech et al., 2009). In general terms, it has been inferred that Late Glacial conditions were dominated by channel and floodplain aggradation followed by pedogenesis during the LP-EH climatic transition. The occurrence of "black mats" was reported in the Late Pleistocene fluvial sequences of the Luján River and related to a Late Glacial global climatic change (Toledo, 2008). The early-middle Holocene was featured by the occurrence of swampy environments associated with fluvial systems (shallow in-stream ponds) likely as a result of waterlogging within the river valleys. In some fluvial basins bioclastic aggradation became dominant during the LP-EH transition and early Holocene (Zárate et al., 2000; Prieto et al., 2004). The observed paleoenvironmental changes have been linked to the prevalence of warmer and more humid climatic conditions in the Pampean plain (Muhs and Zárate, 2001; Zárate et al., 2000; Prieto et al., 2004). It has been pointed out that this climatic condition may have occurred in relation to a shift of maritime tropical air masses to higher latitudes than at present (Kemp et al., 2006; Quattrocchio et al., 2008, and references therein).

At the piedmont plains of the northwestern Pampean Ranges (Llanos de La Rioja, 29 $57^{\prime} \mathrm{S}$ and $65^{\circ} 52^{\prime} \mathrm{W}$, Fig. 1), a complex succession of environmental changes associated with four pedosedimentary cycles was recognized in likely Late Pleistocene and Holocene deposits (Morrás et al., 2010). Further north, in the Bolivian Chaco (Fig. 1), a sensitive area to climatic change placed in the transition between the wetclimate Amazon basin and the subtropical semi-arid-climate Chaco, May et al. (2008) report evidence for late Quaternary paleoenvironmental changes in the paleosol-sediment sequences outcropping in the Rio Grande terraces. There, a well-developed Late Glacial paleosol documents landscape geomorphological stability and wet conditions. Early Holocene likely palustrine sediments provide evidence for flooding events into floodplain environments resulting from a significant increase in winter precipitation and, conversely, decreased summer precipitation (May et al., 2008). Between 11.2 and 8 cal kyr BP, the Bolivian Andes (Fig. 1) have a record of wetlands formation (Servant and Servant-Vildary, 2003).

\subsubsection{Pollen records}

Pollen assemblages from the eastern Andean side at $32^{\circ} \mathrm{S}$ suggest colder and wetter Late Glacial climates than today (Markgraf, 1983). At 32 and $41^{\circ} \mathrm{S}$, postglacial environments were established at $12 \mathrm{kyr}$ BP (Markgraf, 1983). Nothofagus pollen dominated at $41^{\circ} \mathrm{S}$ and higher southern latitudes, while at $32-34^{\circ} \mathrm{S}$ a change from a Late Glacial type grassland with Patagonia floristic affinity to a postglacial type desert scrub - Monte - vegetation occurred (Markgraf, 1983). This modification suggests a shift in the area from winter rain-dominated climate to modern summer 
rain-dominated climate and temperatures values similar to the present-day ones, a pattern that would have lasted until 8.5 kyr BP (Markgraf, 1983).

The alluvial sequence of the Arroyo La Estacada basin reveals halophytic communities and a condition of extreme aridity affecting the piedmont region prior to ca. $10{ }^{14} \mathrm{C} \mathrm{kyr}$ BP (Zárate and Páez, 2002). Eastward, in the Andean foreland, the ca. $12.6 \mathrm{cal} \mathrm{kyr}$ BP high lake levels in the Bebedero saline lake $\left(33^{\circ} 20^{\prime} \mathrm{S}-66^{\circ} 45^{\prime} \mathrm{W}\right.$. Fig. 1) were linked to high water inputs from the Andean fluvial tributaries (Rojo et al., 2012b). Nonetheless, halophytic vegetation developed at that time in the saline lake border areas in response to arid climatic conditions dominating the Andean foreland (Rojo et al., 2012b). The Monte vegetation seems to have been well established by ca. $10{ }^{14} \mathrm{C}$ kyr BP in the Arroyo La Estacada basin and the Bebedero saline lake (Zárate and Paéz, 2002; Rojo et al., 2012b).

At Mallín Vaca Lauquen $\left(\sim 37^{\circ} \mathrm{S}\right)$, the ecotone between the southern limit of the Monte vegetation and the Nothofagus obliqualN. pumilio forest, the Late Glacial-early Holocene (17000-8600 cal yr BP) pollen record indicates cooler and drier summers than today (Markgraf et al., 2009). Markgraf et al. (2009) interpret that this condition might perhaps explain the absence of fires in the area during that interval. In contrast highest fire activity is reported at $35-42^{\circ} \mathrm{S}$ west of the Andes at 11 and 9 cal kyr BP.

At the Chilean side of the Andean belt, marine pollen records at 41 and $46^{\circ} \mathrm{S}$ indicate the development of the North Patagonian rainforest suggesting cool and wet climates before 11.5 and $12 \mathrm{cal} \mathrm{kyr} \mathrm{BP} \mathrm{(Montade} \mathrm{et} \mathrm{al.,} \mathrm{2012,} \mathrm{2013).}$ A deglacial forest expansion took place after $\sim 17.6 \mathrm{kyr} B P$ highlighting the beginning of the last deglaciation and a warming trend (Abarzúa et al., 2010; Montade et al., 2013). The occurrence of Magellanic moorland simultaneously with the Antarctic Cold Reversal, a ca. 1000-year disruption to the Late Glacial warming trend, indicates a pause in the warming and an abrupt increase in precipitation related to strong intensity of southern westerly winds (Montade et al., 2013). Arid conditions dominating early Holocene in the central Andean piedmont of Chile $\left(\sim 32-45^{\circ} \mathrm{S}\right.$, Fig. 1$)$ were attributed to substantially weaker westerlies or latitudinally shifted westerly storm tracks in relation to a strengthened southeastern Pacific High (Jenny et al., 2002; Villa-Martínez et al., 2003; Markgraf et al., 2009, and references therein; Abarzúa et al., 2010). Warmer and drier conditions feature the early Holocene in Chile, which began ca. $11 \mathrm{cal} \mathrm{kyr} \mathrm{BP}$ according to marine pollen cores at 41 and $46^{\circ} \mathrm{S}$ (Montade et al., 2012, 2013). This trend strengthened between 9.6 and $7.4 \mathrm{cal} \mathrm{kyr}$ BP (Montade et al., 2012, 2013).

Regionally, the different pedosedimentary and palynological records mentioned above point to a climatically driven change at the end of the Late Pleistocene leading to the Holocene climatic conditions. It is recorded at both sides of the Andean belt south of the $35^{\circ} \mathrm{S}$, where moisture differences have been indicated since the Late Glacial onwards
(Piovano et al., 2009, and references therein; Markgraf et al., 2009). The Late Glacial paleoenvironmental and paleoclimatic changes, along with the paleoclimatic phases distinguished for the last $13 \mathrm{kyr}$ over Argentina and Chile, have been explained as driven by latitudinal shifts of atmospheric circulation anomalies (Markgraf, 1983). Sedimentological and palynological terrestrial and marine records from central Chile support changes in the strength and/or southwardnorthward shifts of the southern westerly winds - SWWs (Fig. 8a) (e.g., Abarzúa et al., 2010; Montade et al., 2012; Varma et al., 2011, and references therein). An equatorward displacement of the northern SWW margin during glacial periods has been indicated likely resulting in cooler climates (Lamy et al., 2004; Kaiser et al., 2005 and Toggweiler et al., 2006, in Varma et al., 2011). Jenny et al. (2002) inferred, from the Laguna de Aculeo record $\left(34^{\circ} \mathrm{S}\right)$, an arid early Holocene as a consequence of the SWW blocking and deflection southward by the subtropical high-pressure cell.

In the Arroyo La Estacada basin, the early Holocene alluvial sequence recorded the onset of the Holocene climatic conditions at this latitude of the eastern Andean piedmont (Zárate and Páez, 2001, 2002). During the early Holocene, summer sporadic rainfalls generated by storms transporting moisture derived from the Atlantic could have affected this area of the Andean piedmont. Zárate and Páez (2001) suggested the occurrence of heavy and sporadic summer rains affecting the piedmont by that time. The displacement of the westerlies south of $41^{\circ} \mathrm{S}$ and their weakening after $11 \mathrm{kyr} \mathrm{BP}$ (Markgraf et al., 1992), along with the south-westernmost influence of the South Atlantic atmospheric circulation elements, could have been forcing factors of this climatic condition in the study area.

\section{Conclusions}

This work contributes to the knowledge of the dominant paleoenvironmental and paleoclimatic conditions during the Late Glacial to early Holocene climatic transition in the eastern Andean piedmont between 33 and $34^{\circ} \mathrm{S}$. The occurrence of a LP-EH transition paleosol in the alluvial sequences of the Arroyo La Estacada, crossing the frontal cordillera piedmont, records an interval of fluvial basin landscape geomorphological stability. Paleosol features developed in close relation to the climatic conditions dominating the setting of the South American Arid Diagonal at Late Glacial and early Holocene transition. Our observations at the Argentine Andean piedmont between $33^{\circ}$ and $34^{\circ} \mathrm{S}$ are consistent with many other late Quaternary records from the southern tip of South America. Collectively, they display evidence of alternating episodes of sedimentation and pedogenesis at the end of the Pleistocene. The aridity pattern inferred for the Late Glacial in the eastern Andean piedmont was regionally widespread across the Argentinian Pampean region where also a paleosol is recorded at the transition to the Holocene 
climatic conditions. We propose the importance of continuing to unravel the climatic changes that occurred during the transition from Late Glacial to present interglacial conditions in the Andean piedmont.

Acknowledgements. This work was supported by CONICET and the National University of La Pampa, throughout projects PIP 5819 and EXA-186, respectively. Dr. Perla Imbellone is especially thanked for instructing A. Mehl in micromorphological analysis. We are grateful to Dr. Rob Kemp for kindly providing thin sections throughout "Argentinian loess paleosol records of past changes in climate" project. We express our gratitude to Dr. Leandro Rojo for helping during field work and to Hernán Ponce from the Dirección de Recursos Naturales de Tunuyán for providing logistic support. Critical reviews by J.-H. May, M. Zech and P. Sanborn are gratefully acknowledged.

Edited by: A.-L. Daniau

\section{References}

Abarzúa, A. M., Adán, L., De Batist, M., and Maldonado, A.: Glacial to Holocene paleoclimate reconstruction based on laguna las Ranas record in south-central chile $\left(39^{\circ} \mathrm{S}\right)$, in: Proceedings of the 18th International Sedimentological Congress, Mendoza, Argentina, 27 September-1 October 2010, abstracts CD-ROM, p. 91, 2010.

Abraham de Vázquez, E., Garleff, K., Liebricht, H., Regairaz, A., Schabitz, F., Squeo, F., Sting, H., Veit, H., and Villagrán, C.: Geomorphology and palaeoecology of the Arid diagonal in the south America, edited by: Miller, H. and Hervé, F., Z. Angew. Geol., SH1, 55-61, 2000.

Azcuy, C. L.: Las secuencias sedimentarias neopaleozoicas, in: Geologí a y Recursos Naturales de Mendoza, edited by: Ramos, V. A., 12_Congreso Geológico Argentino y $2^{\circ}$ Congreso de Exploración de Hidrocarburos, Mendoza, 10-15 October, I.5, 41-52, 1993.

Baker, V. R.: South American paleohydrology: future prospects and global perspective, Quaternary Int., 72, 3-5, 2000.

Barros, V. R. and Silvestri, G. E.: The relation between sea surface temperature at the subtropical south-central Pacific and precipitation in southeastern South America, J. Climate, 15, 251-267, 2002.

Blasi, A., Zarate, M. A., and Kemp, B. M.: Sedimentación y pedogénesis cuaternaria en el noreste de la pampa bonaerense, LAJSBA, 8, 77-92, 2001.

Boninsegna, J., Argollo, J., Aravena, J. C., Barichivich, J., Christie, D., Ferrero, M. E., Lara, A., Le Quesne, C., Luckman, B. H., Masiokas, M., Morales, M., Oliveira, J. M., Roig, F., Srur, A., and Villalba, R.: Dendroclimatological reconstructions in South America: a review, Palaeogeogr. Palaeocl., 281, 210-228, 2009.

Bullock, P., Fedoroff, N., Jongerius, A., Stoops, G., and Yursina, T.: Handbook for Soil Thin Section Description, Waine Research Publications, Wolverhampton, 152 pp., 1985.

Burgos, J. J. and Vidal, A. L.: Los climas de la República Argentina según la nueva clasificación de Thornwaite, Meteoros 1, 1-32, 1951.
Bruniard, E.: La diagonal árida Argentina: un límite climático real, Rev. Geogr. 95, 5-20, 1982.

Cabrera, A.: Regiones fitogeográficas Argentinas, in: Enciclopedia Argentina de Agricultura y Jardinería, fascículo I, ACME Ed., Buenos Aires, 85 pp., 1976.

Caminos, R.: El basamento metamórfico Proterozoico-Paleozoico inferior, in: Geología y Recursos Naturales de Mendoza, edited by: Ramos, V. A., 12 Congreso Geológico Argentino y $2^{\circ}$ Congreso de Exploración de Hidrocarburos, Mendoza, 10-15 October, I.2, 11-19, 1993.

Catt, J. A.: Paleopedology Manual, Quaternary Int. 6, 1-95, 1990.

Clapperton, C.: Quaternary Geology and Geomorphology of South America, Elsevier, Amsterdam, 779 pp., 1993.

Coronato, A. and Rabassa, J.: Late Quaternary in South America, in: Encyclopedia of Quaternary Science, edited by: Elias, S. A., Elsevier, Amsterdam, 1101-1109, 2007.

Espizua, L. E.: Glaciaciones Cuaternarias, in: Geología y Recursos Naturales de Mendoza, edited by: Ramos, V. A., 12 Congreso Geológico Argentino y 2 Congreso de Exploración de Hidrocarburos, Mendoza, 10-15 October, I.15, 195-203, 1993.

Espizua, L. E.: Quaternary glaciations in the Río Mendoza Valley, Argentine Andes, Quaternary Res. 40, 150-162, 1998.

Espizua, L. E.: Chronology of Late Pleistocene glacier advances in the Río Mendoza Valley, Argentina, Global Planet. Change, 22, 193-200, 1999.

Fidalgo, F., De Francesco, F., and Colado, U.: Geología superficial en las Hojas Castelli, J. M. Cobo y Monasterio (Pcia de Buenos Aires), in: Proceedings of the $5^{\circ}$ Congreso Geológico Argentino, Carlos Paz, Córdoba, 22-28 October, 4, 27-39, 1973.

Frechen, M., Seifert, B., Sanabria, J. A., and Arguiello, G. L.: Chronology of late Pleistocene Pampa loess from the Córdoba area in Argentina, J. Quaternary Sci., 24, 761-772, 2009.

Imbellone, P. A. and Cumba, A.: Una sucesión con paleosuelos superpuestos en la zona sur de La Plata, Lajsba, 10, 3-21, 2003.

Imbellone, P. A. and Teruggi, M. E.: Paleosols in loess deposits of the Argentine Pampa, Quaternary Int., 17, 49-55, 1993.

Jenny, B., Valero-Garcés, B. L., Villa-Martínez, R., Urrutia, R., Geyh, M., and Veit, H.: Early to Mid-Holocene ariditiy in Central chile and the southern westerlies: the laguna Aculeo record $\left(34^{\circ} \mathrm{S}\right)$, Quaternary Res., 58, 160-170, 2002.

Kemp, R. A., Toms, P. S., Sayago, J. M., Derbyshire, E., King, M., and Wagoner, L.: Micromorphology and OSL dating of the basal part of the loess - paleosol sequence at La Mesada in Tucumán province, Northwest Argentina, Quaternary Int., 106/107, 111117,2003

Kemp, R. A., King, M., Toms, P., Derbyshire, E., Sayago, J. M., and Collantes, M. M., Pedosedimentary development of part of a Late Quaternary loess - palaeosol sequence in Northwest Argentina, J. Quaternary Sci., 19, 567-576, 2004a.

Kemp, R. A., Toms, P. S., King, M., and Kröhling, D. M.: The pedosedimentary evolution and chronology of Tortugas, a Late Quaternary type-site of the northern Pampa, Argentina, Quaternary Int., 114, 101-112, 2004b.

Kemp, R. A., Zárate, M., Toms, P., King, M., Sanabria, J., and Arguello, G.: Late Quaternary paleosols, stratigraphy and landscape evolution in the Northern Pampa, Argentina, Quaternary Res. 66, 119-132, 2006. 
Latrubesse, E. M.: The Late-Quaternary palaeohydrology of large South American fluvial systems, in: Palaeohydrology: Understanding Global Change, edited by: Gregory, K. J. and Benito, G., Wiley, Chichester, 193-212, 2003.

Llambías, E. J., Kleiman, L. E., and Salvarredi, J. E.: El magmatismo gondwánico, in: Geología y Recursos Naturales de Mendoza, edited by: Ramos, V. A., 12 Congreso Geológico Argentino y 2 Congreso de Exploración de Hidrocarburos, Mendoza, 10-15 October, I.6, 53-64, 1993.

Lee, J. A. and Kemp, R. A.: Thin sections of unconsolidated sediments and soils: a Recipe, in: Centre for Environmental Analysis and Management Technical Report, Department of Geography, Royal Holloway, University of London, London, UK, 1992.

Markgraf, V.: Late and Postglacial Vegetational and Paleoclimatic changes in Subantarctic, Temperate and Arid environments in Argentina, Palynology, 7, 43-70, 1983.

Markgraf, V., Dodson, J. R., Kershaw, A. P., McGlone, M. S., and Nicholls, N.: Evolution of Late Pleistocene and Holocene climates in the Circum-South Pacific land areas, Clim. Dynam., 6, 193-211, 1992.

Markgraf, V., Whitlock, C., Anderson, R. S., and García, A.: Late Quaternary vegetation and fire history in the northernmost Nothofagus forest region: Mallín Vaca Lauquen, Neuquén province, Argentina, J. Quaternary Sci., 24, 248-258, 2009.

May, J.-H., Zech, R., and Veit, H.: Late Quaternary paleosolsediment-sequences and landscape evolution along the Andean piedmont, Bolivian Chaco, Geomorphology, 98, 34-54, 2008.

McCormac, F. G., Hogg, A. G., Blackwell, P. G., Buck, C. E., Higham, T. F. G., and Reimer, P. J.: SHCal04 southern Hemisphere calibration 0-1000 cal BP. Radiocarbon, 46, 1087-1092, 2004.

Mehl, A. E. and Zárate, M. A.: Late Quaternary alluvial records and environmental conditions in the eastern Andean piedmont of Mendoza (33-34 ${ }^{\circ}$ S, Argentina), J. S. Am. Earth Sci., 37, 41-59, 2012.

Montade, V., Combourier Nebout, N., Chapron, E., Mulsow, S., Abarzúa, A., Debret, M., Foucher, A., Desemt, M., Winiarski, T., and Kissel, C.: Regional vegetation and climate changes during the last $13 \mathrm{kyr}$ from a marine pollen record in Seno Reloncaví, southern Chile, Rev. Palaeobot. Palyno., 181, 11-22, 2012.

Montade, V., Nebout, N. C., Kissel, C., Haberle, S. G., Siani, G., and Michel, E.: Vegetation and climate changes during the last 22,000 yr from a marine core near Taitao Peninsula, southern Chile, Palaeogeogr. Palaeocl., 369, 335-348, 2013.

Morrás, H., Moretti, L., Altinier, M. V., Favret, E., Bressan, E., and Romero, A.: First 5 evidences of several pedo-sedimentary cycles in recent Quaternary sandy deposits in Los Llanos plains, La Rioja (Argentina), in: Proceedings of the 18th International Sedimentological Congress, Mendoza, Argentina, 27 September-1 October 2010, abstracts CD-ROM, p. 618, 2010.

Munsell Soil Color Charts: Munsell Color x-rite, Revised and washable version, Grand Rapids, X-Rite Incorporated, Michigan, USA, 2000.

Muhs, D. R. and Zárate, M.: Late quaternary eolian records of the Americas and their paleoclimatic significance, in: Interhemispheric Climate Linkages, edited by: Markgraf, V., Vol. 12, Academic Press, San Diego, 183-216, 2001.
Navarro, D.: Ambientes holocenos pedemontanos y de Montaña del sur de Mendoza, Ph.D thesis, Universidad Nacional de Mar del Plata, Buenos Aires, Argentina, 2012.

Piovano, E., Damatto Moreira, S., and Ariztegui, D.: Recent environmental changes in Laguna Mar Chiquita (Central Argentina): a sedimentary model for a highly variable saline lake, Sedimentology, 49, 1371-1384, 2002.

Piovano, E. L., Ariztegui, D., Córdoba, F., Cioccale, M., and Sylvestre, F.: Hydrological variability in South America below the Tropic of Capricorn (Pampas and Patagonia, Argentina) during the last $13.0 \mathrm{ka}$, in: Past Climate Variability in South America and Surrounding Regions (Developments in paleoenvironmental research), edited by: Vimeux, F., Sylvestre, F., and Khodri, M., Springer, New York, 14, 323-351, 2009.

Polanski, J.: Estratigrafía, neotectónica y geomorfología del Pleistoceno pedemontano entre los ríos Diamante y Mendoza, Revista De La Asociación Geológica Argentina, 17, 3/4, 127-349, 1963.

Prieto, A. R.: Late Quaternary vegetational and climatic changes in the pampa grassland of Argentina, Quaternary Res., 45, 1, 73-88, 1996.

Prieto, A., Blasi, A., De Francesco, C., and Fernández, C.: Environmental history since $11,000{ }^{14} \mathrm{C}$ yr B. P. of the northern Pampas, Argentina from alluvial sequences of the Luján River, Quaternary Res. 62, 146-161, 2004.

Prieto, M. R., Villagra, P. E., Lana, N. B., and Abraham, E. M.: Utilización de documentos históricos en la reconstrucción de la vegetación de la Llanura de la Travesía (Argentina) a principios del siglo XIX, Rev. Chil. Hist. Nat., 76, 613-622, 2003.

Prohaska, F. J.: Las características de las precipitaciones en la región semiárida pampeana, Revista De Investigaciones Agronómicas, 15, 199-232, 1961.

Quattrocchio, M. E., Borromei, A. M., Deschamps, C. M., Grill, S. C., and Zavala, C. A.: Landscape evolution and climate changes in the Late Pleistocene-Holocene, southern Pampa (Argentina): evidence from palynology, mammals and sedimentology, Quaternary Int., 181, 123-138, 2008.

Rabassa, J.: Late Cenozoic Glaciations in Patagonia and Tierra del Fuego, in: The Late Cenozoic of Patagonia and Tierra del Fuego, edited by: Rabassa, J., Developments in Quaternary Sciences, Elsevier, Amsterdam, 11, 151-204, 2008.

Roig, F. A. and Martínez Carretero, E.: La vegetación puneña en la provincia de Mendoza, Argentina, Phytocenologia, 28, 565-608, 1998.

Rojo, L. D., Mehl, A. E., Páez, M. M., and Zárate, M. A: Midto Late Holocene pollen and alluvial record of the arid Andean piedmont between $33^{\circ}$ and $34^{\circ} \mathrm{S}$, Mendoza, Argentina: inferences about floodplain evolution, J. Arid Environ. 77, 110-122, 2012a.

Rojo, L. D., Páez, M. M., Chiesa, J. O., Strasser, E. N., and Schäbitz, F: Palinología y condiciones paleoambientales durante los últimos 12.600 cal. años AP en salinas del Bebedero (San Luis, Argentina), Ameghiniana 49, 427-441, 2012b.

Saltzman, B.: Dynamical Paleoclimatology, Generalized Theory of Global Climate Change, International Geophysics Series, Vol. 80, Academic Press, New York, London, 392 pp., 2002.

Servant, M. and Servant-Vildary, S.: Holocene precipitation and atmospheric changes inferred from river paleowetlands in the Bolivian Andes, Palaeogeogr. Palaeocl. Palaeoecol. 194, 187-206, 2003. 
Soil Survey Staff: Soil Taxonomy: a Basic System of Soil Classification for Making and Interpreting Soil Surveys, Natural Resources Conservation Service, 2nd Edn., US Department of Agriculture, Washington, D.C., 870 pp., 1999.

Soil Survey Staff: Keys to Soil Taxonomy, Natural Resources Conservation Service, 9th Edn., US Department of Agriculture, Washington, D.C., 334 pp., 2003.

Sruoga, P., Llambías, E. J., Fauqué, L., Schonwandt, D., and Repol, D. G.: Volcanological and geochemical evolution of the Diamante Caldera - Maipo Volcano Complex in the southern Andes

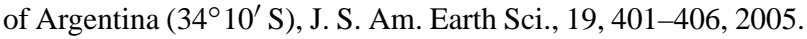

Teruggi, M. E. and Imbellone, P. A.: Paleosuelos loéssicos superpuestos en el Pleistoceno superior - Holoceno de la región de La Plata. Provincia de Buenos Aires, Argentina, Ciencia Del Suelo, 5, 175-188, 1987.

Toledo, M. J.: La crisis climática de 13.000 AP: "mantos negros", extinciones de megafauna y cambios poblacionales, in: Proceedings of the 17th Congreso Geológico 5 Argentino, San Salvador de Jujuy, 7-10 October, 735-736, 2008.

Toms, P. S., King, M., Zárate, M. A., Kemp, R. A., and Foit Jr., F. F.: Geochemical characterization, correlation, and optical dating of tephra in alluvial sequences of central western Argentina, Quaternary Res., 62, 60-75, 2004.

Tripaldi, A. and Forman, S. L.: Geomorphology and chronology of Late Quaternary dune fields of western Argentina, Palaeogeogr. Palaeocl., 251, 300-320, 2007.

Tripaldi, A., Zárate, M. A., and Brook, G. A., and Li, G.-Q.: Late Quaternary paleoenvironments and paleoclimatic conditions in the distal Andean piedmont, southern Mendoza, Argentina, Quaternary Res., 76, 253-263, 2011.

Tucker, M. E.: Sedimentary Rocks in the Field, 3rd Edn., John Wiley \& Sons Ltd, Chichester, 234 pp., 2003.

Varma, V., Prange, M., Lamy, F., Merkel, U., and Schulz, M.: Solarforced shifts of the Southern HemisphereWesterlies during the Holocene, Clim. Past, 7, 339-347, doi:10.5194/cp-7-339-2011, 2011.

Villalba, R.: Climatic fluctuations in northern Patagonia during the last $1000 \mathrm{yr}$ as inferred from tree-ring records, Quaternary Res., 34, 346-360, 1990.

Villa-Martínez, R., Villagrán, C., and Jenny, B.: The last $7500 \mathrm{cal}$ yr B.P. of westerly rainfall in Central Chile inferred from a highresolution pollen record from Laguna Aculeo ( $\left.34^{\circ} \mathrm{S}\right)$, Quaternary Res., 60, 284-293, 2003.
Yrigoyen, M.: Los depósitos sinorogénicos terciarios, in: Geología y Recursos Naturales de Mendoza, edited by: Ramos, V. A., $12^{\circ}$ Congreso Geológico Argentino y $2^{\circ}$ Congreso de Exploración de Hidrocarburos, Mendoza, 10-15 October, I.17, 217 234, 1993.

Zárate, M. A.: Geología y Estratigrafía del Pleistoceno tardíoHoloceno en el piedemonte de Tunuyán-Tupungato, Mendoza, Argentina, in: Proceedings of the $15^{\circ}$ Congreso Geológico Argentino, El Calafate, Santa Cruz, Argentina, 23-26 April 2002, 615-620, 2010.

Zárate, M. A. and Mehl, A.: Estratigrafía y geocronología de los depósitos del Pleistoceno Tardío / Holoceno de la cuenca del Arroyo La Estacada, departamentos de Tunuyán y Tupungato (Valle de Uco), Mendoza, Revista De La Asociación Geológica Argentina, 63, 407-416, 2008.

Zárate, M. A. and Páez, M. M.: Paleoambientes y paleoclimas de la transición Pleistoceno- Holoceno entre los $32-38^{\circ} \mathrm{S}$ de $\mathrm{Ar}-$ gentina, in: Anáis do VIII Congresso da Associação Brasileira de Estudos do Quartenário (ABEQUA), Porto Alegre, 14-20 October 2001, abstracts, 350-351, 2001.

Zárate, M. A. and Páez, M. M.: Los paleoambientes del Pleistoceno tardío-Holoceno en la cuenca del Arroyo La Estacada, Mendoza, in: IANIGLA, 30 años de investigación básica y aplicada en ciencias ambientales, edited by: Trombotto, D. and Villalba, R., Ianiglia, Mendoza, 117-121, 2002.

Zárate, M. A., Kemp, R. A., Espinoza, M., and Ferrero, L.: Pedosedimentary and palaeoenvironmental significance of a Holocene alluvial sequence in the southern Pampas, Argentina, Holocene, 10, 481-488, 2000.

Zárate, M. A., Kemp, R. A., and Blasi, A. M.: Identification and differentiation of Pleistocene paleosols in the northern Pampas of Buenos Aires, Argentina, J. S. Am. Earth Sci., 15, 303-313, 2002.

Zech, W., Zech, M., Zech, R., Peinemann, N., Morrás, H. J. M., Moretti, L., Ogle, N., Kalim, R. M., Fuchs, M., Schad, P., and Glaser, B.: Late Quaternary palaeosol records from subtropical $\left(38^{\circ} \mathrm{S}\right)$ to tropical $\left(16^{\circ} \mathrm{S}\right)$ South America and palaeoclimatic implications, Quaternary Int., 196, 107-120, 2009.

Zinck, J. A. and Sayago, J. M.: Loess-paleosol sequence of La Mesada in Tucuman province, Northwest Argentina characterization and paleoenvironmental interpretation. J. S. Am. Earth Sci., 12, 293-310, 1999. 